\title{
Mulheres da Educação de Jovens e Adultos em busca da formação perdida: um olhar da educação musical ${ }^{1}$
}

\section{Women in Youth and Adult Education in search of their lost schooling: an overview on music education}

\author{
Maria Guiomar Ribas ${ }^{2}$
}

\begin{abstract}
RESUMO
Este trabalho está baseado em dados empíricos de uma pesquisa sobre música na Educação de Jovens e Adultos (EJA). Trata-se de um estudo de caso realizado em uma escola pública em Porto Alegre-RS, cujos resultados mostram que aprendizagens musicais se tecem por meio de uma articulação entre os(as) estudantes, permeada por conflitos e trocas geracionais. O recorte desse artigo incide sobre as mulheres participantes da referida pesquisa, considerando suas experiências educativas e musicais antes, bem como durante a EJA. O objetivo do presente trabalho é refletir sobre a educação escolar e musical dessas mulheres, cujas buscas de formação quando crianças e jovens resultaram em exclusão, interrupções, falta de acesso, porém, chegando posteriormente à realização da escolaridade por meio da EJA. Associado a esse debate da escolaridade e música no cenário da EJA, abordam-se as categorias geracionais baseando-se em estudos das ciências sociais e humanas.
\end{abstract}

Palavras-chave: mulheres e música na EJA; música na EJA; EJA e Educação musical.

DOI: $10.1590 / 0104-4060.36585$

1 Artigo gerado a partir da pesquisa de doutorado desenvolvida sob orientação da prof. Dra. Jusamara Souza, no Programa de Pós-Graduação em Música (PPGM) da Universidade Federal do Rio Grande do Sul (UFRGS). Bolsa da Coordenação de Aperfeiçoamento de Pessoal de Nível Superior - CAPES (2002-2006).

2 Universidade Federal da Paraíba. João Pessoa, Paraíba, Brasil. Campus I. Bairro Castelo Branco. CEP: 58051-900. 


\begin{abstract}
This work is based on empirical data from a research about music in Youth and Adult Education (Educação de Jovens e Adultos - EJA). It was carried out on a case study in a public school in Porto Alegre, Brazil. Its results show that the musical learning process is achieved through an interaction permeated by some conflicts, as well as by exchanges among students of different generations. This article focuses on women participating in this research, considering their educational and musical background before, as well as during the EJA experience. The paper's aim is to reflect upon schooling, including the music education of these women, whose search for education as children or as youths found exclusion, interruptions and a lack of access to school. However, the attainment of education through EJA came after. Associated with this debate related to music and education in EJA, it has approached the generational subject, based on studies in the field of social science and humanities.
\end{abstract}

Keywords: women and music in EJA; music in EJA; EJA and music education.

\title{
Introdução
}

Ao longo das últimas décadas, a Educação de Jovens e Adultos (EJA) vem ocupando espaços de debate, investigação e interlocução no campo das políticas públicas, estando dirigida não apenas à área de ensino, mas também integrando diferentes centros de pesquisa e formação, no país, que têm gerado inúmeras publicações e estudos científico-acadêmicos. Várias destas produções passaram a compor planos de políticas sociais de ação no campo da educação, da saúde, dos estudos geracionais, da melhoria da qualidade de vida, da formação continuada e integral, entre outros. A associação entre educação, fatores geracionais e cidadania tem se mostrado como uma aliança muito profícua para a formulação de políticas públicas de ação social e de formação profissional, e no caso da EJA, o mesmo vem ocorrendo (SOARES; VENANCIO, 2007; OLIVEIRA, 2007; LAFFIN, 2007). Dessa maneira, a produção científica na área da EJA tem se tornado expressiva e ultrapassado continentes, buscando articulações entre paradigmas teóricos, campos disciplinares, políticas de formação escolar e não escolar, experiências culturais e intergeracionais, e propostas de formação e capacitação dos educadores nesta área (SOUZA, 2000; MOLL, 2004). Estas interconexões têm mostrado que os processos de aprendizagem e formação podem e deveriam ser contínuos, ao longo da vida (lifelong learning-education) 
(HADDAD, PIERRO, 2000; SOUZA, 2000), assim como também poderiam se aliar a outros campos disciplinares, com a finalidade de potencializar e fortalecer esses processos formativos (FREITAS, 2007; BRANCO, 2007). Assim é que se pode também refletir sobre possíveis liames entre educação, EJA e música, como apresentado no presente artigo.

A EJA tem se dedicado à chamada escolaridade "tardia", ou seja, aquela que acontece posterior à idade prevista para iniciar a educação básica, sendo dirigida a pessoas com mais de 14 anos, não havendo limite à idade máxima. Neste cenário, a entrada e a utilização da música, em diferentes contextos escolares, podem ser vistas como elementos potencializadores para as diferentes aprendizagens, incentivando também o convívio interpessoal entre estudantes de diferentes idades. Esta modalidade de ensino foi considerada um espaço privilegiado de aprendizagem intergeracional (RIBAS, 2006), uma vez que se faz inerente à sua cultura escolar o convívio entre pessoas de diferentes gerações, e mais especificamente, em uma mesma sala de aula. Ao propiciar a convivência de estudantes de diferentes idades, a EJA promove tensionamentos e trocas geracionais que repercutem nas formas pelas quais se aprende e se compartilham saberes.

Este trabalho toma como base dados empíricos de uma pesquisa no campo da educação musical sobre música na Educação de Jovens e Adultos (EJA). Seu objeto foi construído a partir da articulação de três eixos temáticos - música, EJA e intergeracionalidade - e seu objetivo consistiu em compreender como se articulam aprendizagens e práticas musicais entre estudantes de diferentes gerações da EJA (RIBAS, 2006).

A pesquisa desenvolvida, seguindo os moldes de um estudo de caso de orientação qualitativa, teve por locus o Centro Municipal de Educação de Trabalhadores Paulo Freire (CMET) - uma escola pública da EJA em Porto Alegre, que atendia na ocasião, em seus três turnos, aproximadamente 1.400 estudantes, contando com duas professoras de música, que ministravam aulas e oficinas. Os instrumentos utilizados para a obtenção dos dados foram: observação; entrevista semiestruturada; análise de documentos; dirigidos ao registro e à coleta das visões desses estudantes sobre a formação escolar e a formação musical. Na pesquisa toda, objeto do doutorado desta autora, foram entrevistados(as) 17 estudantes, cujas idades variaram entre 21 a 78 anos, sendo nove mulheres e oito homens oriundos dos estratos populares.

Assim, considerando-se a proposta do presente artigo, objetiva-se refletir sobre a educação escolar e musical das mulheres da EJA participantes desta pesquisa, cujas buscas anteriores de formação se revelam permeadas por interrupções, ocasionadas em grande medida pela falta de acesso ao processo educacional dito formal. Entretanto, após alguns anos, estas mulheres puderam, 
em certa medida, chegar à realização da escolaridade pelo fato de terem se aproximado desta forma de educação através da participação em cursos da EJA.

Apresentam-se aqui os depoimentos de nove mulheres entrevistadas quanto às suas experiências educativas e musicais anteriores, assim como durante o processo de educação na EJA. Os resultados mostram que as aprendizagens musicais são tecidas por meio de uma articulação entre pares, permeada por conflitos e trocas geracionais, o que sugere um debate a respeito das condições da escolarização em diferentes gerações e suas relações com as práticas e aprendizagens musicais no cenário da EJA. Para isso, também, foram considerados alguns aspectos relativos às categorias geracionais abordando-as como construtos sociais e heterogêneos, baseados em estudos de Bourdieu (1983), Pais (1993), Lloret (1997), Debert (2004), entre outros.

\section{Concepções a respeito da intergeracionalidade}

As ideias que permeiam, neste texto, o conceito geracional (geração) se apoiam em estudos do campo das ciências humanas, em que as categorias etárias têm sido utilizadas como elemento de representação e organização social. Lloret (1997) mostra que a idade tende a imprimir, no sujeito, marcas de conduta e comportamento, considerados legítimos ou não, apropriados ou não. Por entender que tendemos a condicionar as experiências vividas àquelas naturalizadas e consideradas pertinentes de acordo com o pertencimento geracional, essa autora provoca seus leitores(as), ao afirmar que "a idade não é sua nem minha, é a idade do outro que, a nos ser dada, nos possui. Nessa expropriação de nossas diferenças cronológicas, nosso próprio tempo fica aprisionado" (LLORET, 1997, p. 13). Nessa direção, algumas participantes da pesquisa em tela, quando indagadas sobre suas idades, revelaram estranhamento. Isso ocorreu, por exemplo, com uma entrevistada que ao longo do trabalho de campo omitia esse dado, dizendo possuir, vagamente, "uns 60 anos". No depoimento que segue, outra entrevistada mostra incerteza acerca da própria idade:

Parece que estou com uns 70 nuns papéis, noutro eu estou com 78. Mas eu acho que estou com uns 68, 67, uma coisa assim. Não que eu não queira ser velha, a idade que eu tiver... que coisa boa! Mas lá no Cartório colocaram 78. (Célia Outono) 
Tendemos a assumir, em nossas relações interpessoais, atitudes e comportamentos considerados próprios da idade relacionados à cultura e sociedade em questão, evidenciando que as maneiras pelas quais a vida é periodizada são criadas socialmente. Um exemplo atual é o surgimento de categorias intermediárias entre a fase adulta e a velhice, denominada terceira idade, e, ainda mais recentemente, a quarta idade (DEBERT, 2004). Para além de meras etapas biológicas, as gerações ${ }^{3}$ são categorias socialmente construídas, como afirmam Bourdieu (1983), Ariès (1981) e Lloret (1997).

O entendimento da criança como sujeito social é uma construção que se deu na modernidade, e, posteriormente, o(a) jovem passou a ser assim compreendido(a), "empurrando a infância para trás e a maturidade para frente", conforme discute Ariès (1981, p. 47). Nessa ocasião, não havia um termo referente à fase de vida adulta, "[...] as pessoas passavam sem transição de juvenes a sener" (ARIÈS, 1981, p. 167). Acrescenta esse autor que antes disso havia imprecisão e desconhecimento acerca da idade, embora a partir do século XVI a idade passou a significar uma referência, possibilitando às famílias certa consistência social e histórica.

Há uma variabilidade de formas de conceber e viver as fases da vida. Em interface com outros pertencimentos como etnia, classe social, religião e gênero, as pessoas vão assumindo maneiras diversas de serem jovens, adultos, etc.; o ser humano é per si plural. Essa diversidade problematizada do ponto de vista intrageracional é considerada por Bourdieu (1983). Ao abordar as diferenças entre as juventudes, esse autor afirma que "o fato de falar dos jovens como se fossem uma unidade social, um grupo constituído, dotado de interesses comuns, e relacionar esses interesses a uma idade definida biologicamente, já constitui uma manipulação evidente" (BOURDIEU, 1983, p. 113). Para Bourdieu (1983) não cabe falar de juventude, mas sim juventudes; posta sua heterogeneidade.

Outros estudos no campo das humanidades abordam a heterogeneidade enquanto condição humana, portanto transversalizando o convívio entre as pessoas, quer de uma mesma geração ou de várias. Pais (1993), por exemplo, em sua tese intitulada "Culturas Juvenis", contribui para a desmistificação da suposta unidade nessa fase de vida ao trazer as diferenças nos modo de ser entre jovens portugueses de Lisboa (PAIS, 1993, p. 28). A velhice é tema abordado por Motta (1998) e por Debert (2004), cujas teses mostram múltiplos valores, atitudes e comportamentos de pessoas idosas, também desmistificando padrões sociais até então dominantes. Nessa perspectiva, Vianna (2003) argumenta: “[...] A totalidade da vida social pode então ser definida com muitas das palavras

3 Ao longo do texto o termo geração é usado como sinônimo de: idade; fase de vida; e categoria etária. 
que um dia identificaram a juventude: transitoriedade, turbulência, agitação, ambiguidade, liminaridade, flexibilidade, inquietude" (VIANNA, 2003, p. 14). Esses, entre outros estudos, podem contribuir para um enfrentamento aos estereótipos, presentes também nas discussões e temáticas relativas aos processos intergeracionais, e com isso podem colaborar para análises mais sólidas sobre este fenômeno, e para possíveis alternativas na vida cotidiana dessas pessoas.

\section{Sobre as formações perdidas}

Para a compreensão desse tópico interessam particularmente as experiências dessas mulheres da EJA com a escolaridade, que se entrelaçam com o trabalho e as relações familiares. Assim, apresentando as nove mulheres participantes da pesquisa, quatro não iniciaram ou interromperam sua educação escolar devido às demandas domésticas como criação de filhos(as) ou irmãos(as). E cinco delas, devido à necessidade de trabalhar desde o período em que viviam com suas famílias de origem, permaneceram trabalhando quando se casaram. Quatro delas são aposentadas e as profissões indicadas são: cozinheira, diarista, enfermeira, empregada doméstica e autônoma. Nesse sentido, o perfil sócio-ocupacional destas mulheres trabalhadoras vai ao encontro da literatura específica que mostra que a maioria dos(as) estudantes da EJA é constituída por pessoas das classes populares (SMED, 1997).

A vida dessas mulheres é marcada pela evasão escolar, não acesso às instituições de ensino e interrupção da escolaridade. Seus relatos mostram que fatores diversos dificultaram a experiência escolar na idade esperada para o ingresso educacional. Havia duas delas que não ingressaram na escola por falta de acesso ao ensino na região em que moravam, quer por sua quase inexistência, quer por preconceito. É o caso de Inocência (68 anos), que conta que na década de 1950 não havia escola pública onde morava e, posteriormente, quando o município passou a contar com uma instituição pública de ensino, esta parecia ser prioritariamente destinada aos "brancos". Ela recorda:

Eu sempre tive muita vontade de estudar. [...] Não podia estudar porque tinha de trabalhar na roça para ajudar meus pais. E quando aconteceu de ter um colégio lá para estudar, tinha muito preconceito, então ali onde estavam estudando os brancos, os negros não podiam estudar. Isso foi uma coisa horrivel para nós. A gente ficou com aquilo de não 
poder estudar, de sempre ser humilhada porque não sabia ler, não sabia escrever, não podia estudar, porque só tinha branco. (Inocência)

A família de Inocência (68 anos) é constituída por ela, seu marido (que também é aluno da Escola), sua sogra, uma neta e um bisneto, mas aposentou-se como empregada doméstica - trabalhou por mais de 20 anos em uma mesma casa em Porto Alegre. "Eu criei os filhos dela que são médicos. Eles ainda me chamam de mãe preta" (Inocência).

O não acesso à escola também é mencionado por Tereza (67 anos), que mora com seu marido. Além disso, dedicou-se integralmente a compromissos familiares ao casar. Ela conta seu processo de interrupção escolar:

Estudei até a terceira série. Quando eu tinha 9 anos, fui para a escola, eu e meus três irmãos. Estava tudo muito bom, incendiou a escola. Ficamos cinco anos sem escola, ai eu já estava com 13 anos e tinha vergonha de estar na mesma sala com os pequenos. Eu vim pra cidade para ir para a escola, nisso eu já estava com 17 anos. Fiz matrícula e tudo, fui um mês, mas depois não pude mais, porque minha irmã ganhou nenê, eu estava na casa dela, na cidade. Depois fui namorar, casar e ai o estudo foi ficando para trás. (Tereza)

Similarmente, Ereni (65 anos), que vive com o marido, aposentado do exército, taxista, e dois filhos(as), interrompeu seus estudos aos 12 anos, pois onde morava havia uma única escola que atendia até a quarta série do então ensino primário. Concluída a quarta série, passou a ajudar o pai na lavoura, mas logo a família se mudou para a capital à procura de melhores condições de vida. Aos 20 anos ela casou, e, com as demandas da família, Ereni (65 anos) postergou a volta à escola por décadas.

O casamento também levou Jaqueline (34 anos) a parar de estudar aos 18 anos de idade. Separada, é mãe de cinco filhas e mora na casa do pai. Trabalha como diarista; no entanto, pretende ser cantora profissional ou funcionária da polícia municipal.

Assim como as mulheres justo acima mencionadas, Célia Outono (78 anos) parou de estudar quando casou aos 13 anos de idade. Filhos(as) e a relação conjugal dificultaram sua permanência na escola. Viúva, ela tem quatro filhos(as), sendo três homens e uma mulher. Os três filhos já constituíram suas próprias famílias e sua filha mora com ela. Célia Outono (78 anos) não trabalhou fora de casa; recebe a aposentadoria deixada pelo marido. 
$\mathrm{O}$ estranhamento à cultura escolar vigente aparece em alguns relatos. Iara (49 anos) é separada e seus dois filhos moram com ela. Quando realizamos a última entrevista, havia se aposentado há poucos meses como enfermeira em um hospital de Porto Alegre. Inadequação às formas conservadoras de ensino levou Iara (49 anos) a abdicar da escola quando criança:

Fiz até a segunda série. Depois eu nunca mais estudei porque acho que me traumatizei um pouco com a matemática quando eu era pequena [...] Toda quarta-feira era dia de tabuada e eu nunca sabia, porque já tinha medo. Eu e meu irmão muitas vezes a gente ficava até as duas horas [de castigo]. [...] Eu fiquei uns cinco anos na segunda série, não saía daquilo. Até que um dia disse pro meu pai: "Pai, eu não vou estudar, não adianta, eu não tenho condições de estudar". Aí, comecei a trabalhar. (Iara)

Solteira e morando com seu pai e mãe, Célia Primavera (30 anos) interrompeu seus estudos aos 14 anos quando assumiu a criação dos irmãos, enquanto seu pai e mãe trabalhavam fora. Mora com seus pais na zona norte da cidade e pretende ingressar no mundo do trabalho após terminar o curso no CMET. Ocasionalmente auxilia a mãe que é diarista. Da mesma forma, Maria Helena (64 anos), interrompeu seus estudos inicialmente pela demanda doméstica da família de origem: "Eu fui na aula até uns 12 anos, mas depois parei, não fui mais, eu ajudava minha mãe" (Maria Helena). Depois, passou a trabalhar fora de casa. Trabalhou como cozinheira e confeiteira durante quarenta e três anos em restaurantes privados e na Receita Federal. Aposentada há dez anos, ressalta que continua trabalhando. Maria Helena está separada e um de seus dois filhos mora com ela.

Diva (72 anos) parou de estudar aos 14 anos de idade ao assumir seu primeiro emprego em uma fábrica de tecelagem e fiação. Como esse trabalho se dava por turnos, ficou inviabilizada sua permanência na escola. Posteriormente casou, permaneceu trabalhando, no entanto seus compromissos com a família, principalmente a criação do seu filho, fez com que continuasse adiando o retorno à escola. Aposentou-se após trabalhar por quase sessenta anos.

Tais relatos mostram que em seus percursos de vida, essas mulheres das classes populares enfrentaram situações diversas de discriminação de classe, etnia e gênero que minimizaram ou mesmo destituíram a possibilidade de estudar quando crianças e jovens. Souza (2000) alega que ser privado do acesso à educação básica "é, de fato, a perda de um instrumento imprescindível para a presença significativa na convivência social contemporânea" (SOUZA, 2000, p. 24), passando a construção da cidadania por sua superação, e, tendo a EJA um papel de suma importância nesse sentido. 


\section{Experiências escolares das entrevistadas na EJA}

Diversos estudantes da EJA visam instrumentalizar-se para galgar melhorias no trabalho ou conseguir um emprego, buscando na educação bases para isso (MOLL, 2004; SOUZA, 2000). Este foi o caso de Célia Primavera (30 anos), Jaqueline (34 anos) e Maria Helena (64 anos). Já entre as estudantes mulheres aposentadas ou que jamais trabalharam fora de casa, outros são os motivos. Tereza (64 anos) e Iara (49 anos) procuraram na escola os meios para melhor interagir com as pessoas, donde particularmente destacam a relação com os(as) filhos(as). "Eu quero saber mais das coisas para conversar melhor com meus filhos" (Iara). Para Tereza (64 anos) a vontade de estudar foi aumentando com o passar dos anos, acentuada pela necessidade de comunicar-se através de cartas com uma filha:

Às vezes chegava carta para mim e uma filha dizia: "Mãe, chegou carta para ti". Ela foi crescendo, lendo e escrevendo as cartas para mim. A outra filha que mandava as cartas falava que eu estava escrevendo muito ruim. É que quando eu ia escrever esquecia $r$, $s$, trocava tudo. Essa filha disse: "Mãe tu estás esquecendo como escreve, arruma uma escola para ti". (Tereza)

Já Jaqueline (34 anos) voltou a estudar após a separação. Ingressou no CMET por indicação da tia e da prima, ambas, estudantes da Escola. Afirma que um dos fatores que lhe levou a procurar essa Escola foi justamente a presença da música. Ela conta:

Eu sempre gostei de música, mas sempre fui barrada pela família, porque eu casei cedo. E daí a minha prima falou: "Olha, tem até aula de canto lá, tem coral". Mas ela não explicou como é que era. Ai eu vim para estudar de noite e vi que tinha técnica vocal. Então me escrevi das cinco às sete na oficina de música, e eu vou também para a minha aula de música. (Jaqueline)

O convívio geracional como sendo de grande valor na Escola foi um aspecto comum nos depoimentos. Diva (72 anos) voltou a estudar após sua 
aposentadoria, por considerar que sabia pouco. Acerca da interação com colegas de diferentes idades, ela tece a seguinte reflexão: "Eu digo assim, os jovens têm de conviver com os velhos, e os velhos têm de conviver com os jovens. Quando a gente diz que antes não tinha água encanada, que o banho era de bacia, que eu ia lavar roupa no rio, eles parecem que não acreditam" (Diva). Para ela a relação intergeracional "serve até para ganhar experiências" (Diva), indo ao encontro do pensamento de Oliveira (1999), autor que defende que independentemente da condição etária, pode-se aprender e mudar a partir da convivência com o outro, enriquecendo-se mutuamente através das aprendizagens compartilhadas entre gerações diversas.

O depoimento de Iara (49 anos) remete ao relativismo dos conceitos jovem e velho. Ela considera estimulante o convívio intergeracional na Escola: "Eu acho que é uma motivação para a gente estar com essas pessoas. Bah, é uma das coisas daqui da Escola que eu mais adorei e adoro. Acho que elas são pessoas maravilhosas, tanto é que voltaram a estudar. Eu sou mais jovem, mas me relaciono bem com elas" (Iara).

No entanto, Maria Helena (64 anos) menciona a dificuldade que teve no processo de adaptação à Escola. Para ela lidar com os mais jovens foi desafiante. Pensou em abandonar a Escola, mas consegue adotar um olhar mais compreensivo, aprendendo nesse convívio a superar conflitos e estereótipos geracionais:

Porque o mau elemento não está só no jovem, está nas pessoas idosas também; às vezes é bem de idade e bem sem-vergonha e o que eu mais prezo é o bom caráter. Ter bom caráter, confiança, fazer muita amizade, não abusar. [...] E aqui têm pessoas de todos os niveis; por isso mesmo é uma escola. As professoras estão aí para isso mesmo. Que é difícil,é, mas eu gosto daqui. (Maria Helena)

Ereni (65 anos) mostra sua visão de como os mais jovens e os mais velhos lidam com o aprendizado, sugerindo que os mais jovens aprendem com maior rapidez do que os mais velhos, embora ela própria, depois de quase cinquenta anos sem estudar, tenha retomado a escola e concluído o ensino fundamental na EJA em menos de três anos superando a si mesma.

Os jovens parecem que gravam mais rápido as coisas. Mas nós vamos devagar e sempre, né [risos]. Eu custei, faz mais de dois anos que eu 
estou estudando. Eu acho que eu sou demorada, eu penso mais rápido. Agora é importante o tempo para mim porque eu já estou numa idade em que não posso perder mais um dia da minha vida [risos], então eu acho que eu demoro, se eu tivesse tempo ainda para ir devagarzinho tudo bem, mas não tenho, por isso eu acho que eu sou demorada. (Ereni)

Célia Primavera (30 anos) considera o ambiente educacional da EJA como sendo de troca, e comenta: "A mais velha estudante aqui tem quase 90 anos. Não tem essa de chegar na secretaria e dizer 'quero tudo da minha idade'. Não, na minha turma, apesar das briguinhas, são todos chegados" (Célia Primavera). Diz se relacionar melhor com colegas mais idosos, uma vez que, segundo ela, os mais velhos têm mais força de vontade.

A decisão de estudar estava baseada na necessidade de Inocência (68 anos) de "saber alguma coisa, por que isso faz muita falta". Assim Inocência, para quem "o estudo é tudo", descobre o CMET através de uma amiga. Iniciou seus estudos "em 04 de abril de 2000!" [Falando de modo enfático para destacar a importância dessa data para ela]. Inocência (68 anos), que viveu de modo marcante facetas da exclusão social desde sua infância, mostra como a EJA passa a ser importante no sentido de ajudá-la a superar esse trauma:

Ah, desde o dia em que eu cheguei aqui, eu sempre fui muito bem recebida. Não tem aquela coisa de preconceito. A gente já ganhou aquele carinho das professoras, da direção, dos funcionários. A gente aqui se sente à vontade, a gente sente aquele querer de estudar. Porque não tem essa coisa de preconceito, a direção, a professora não deixa que isso aconteça. Para a gente isso é uma maravilha; para mim, principalmente, é uma coisa fora do sério. Então eu tenho aquele prazer, aquele querer de estudar. (Inocência)

A relação dessas estudantes pesquisadas com a escola demonstrou-se intensa. Suas falas sugerem que a EJA representa um espaço de aprendizagem e prazer; lugar onde se sentem acolhidas e estimuladas a superar dificuldades na esperança de resignificar sua posição na vida social. O respeito e apoio mútuo mostram-se prevalecentes nesse cenário, cujos indivíduos parecem ter em comum a vontade de aprender e compartilhar conhecimentos. 


\section{Experiências musicais anteriores à escola}

Small (1984) aborda a distinção entre escolaridade e educação musical, lembrando que o ato de educar transcende a escola. Pelo menos desde os anos 1970, o autor defende que outros espaços fora da escola podem se constituir em espaços de formação musical. Trazendo referências da educação e da sociologia, esse autor critica o modelo escolar dominante por lidar com o conhecimento como uma instância fora do universo vivencial do indivíduo, buscando prepará-lo para o consumo e reprodução e não para a produção de conhecimento. No entanto, como ele defende, "a experiência individual constitui o coração da aprendizagem" (SMALL, 1984, p. 204). Por sermos seres sociais, necessitamos partilhar as experiências que nos são significativas, daí Small (1984) afirmar ainda que o aspecto vivencial da música está intrinsecamente ligado ao comunitário.

A formação musical das mulheres participantes da pesquisa vai ao encontro dessas ideias. Para várias delas, o contato inicial com a música se deu através da família. Conforme relatam, conhecimentos e gostos musicais são adquiridos pelas relações travadas entre parentes, como é o caso de Ereni (65 anos), que tem como prática musical corrente o canto em família. Juntamente com uma das suas noras, ela canta, com o auxílio do karaokê, nos almoços dominicais, nas férias e em outros momentos de confraternização familiar. Além da família, outros contextos como o religioso e o midiático radiofônico se apresentaram como espaços significativos de práticas e aprendizagens musicais.

Diva (72 anos) teve uma infância permeada de música. Sua formação musical se deu em grande parte através da orquestra de baile de seu pai. Seus cinco irmãos e um primo integravam a orquestra. Sua irmã tocava violão, mas não participava, pois como comentou: "naquele tempo mulher não participava em nada disso" (Diva). Tocavam rancheira, xote, valsa e tango em bailes e participavam em Ternos de Reis em Porto Alegre. Embora não tenha integrado a orquestra, Diva (72 anos) diz que sentia a música, acompanhando os ensaios e apresentações musicais desse grupo familiar. Como ela contou, escutava essa orquestra por trás da porta; atenta. Assim, a apreciação musical foi exercitada por ela desde criança. Essa entrevistada salientou o aspecto ativo da escuta musical ao ser perguntada se participava dessa orquestra: "Sim, sim, eu participava, eu era muito curiosa. Eu espiava os ensaios e os bailes em casa também, [mas] eles não deixavam eu ir para a sala da frente" (Diva). Diva (72 anos) não toca um instrumento, mas diz gostar muito de ouvir música.

Jaqueline (34 anos) vem de uma família de músicos. Seu pai fundou duas escolas de samba na cidade de São Leopoldo durante sua infância. Seus irmãos 
eram mestres na caixeta ${ }^{4}$ e seu ex-marido mestre no surdo ${ }^{5}$ dessas escolas de samba. Assim como ocorreu com Diva (72 anos), o pai dela não permitiu que ela integrasse o grupo musical familiar. Jaqueline (34 anos) diz que sua vontade de cantar foi inspirada em seu avô seresteiro e sua tia cantora:

Quando eu era pequena, vovô gostava muito de tocar violão e ele cantava [recorda cantando] abre a janela, venha ver a noite bela, venha ver o sol raiar [risos]. E eu ficava escutando, escutando aquilo. E a minha tia também, ela tinha um conjunto quando era mais nova. Era tipo as músicas da Wanderléia, Jovem Guarda [recorda novamente cantando] [...] pobre menina não tem ninguém. Quando eu era pequena eu sempre dizia que ia ser cantora, mas que eu não tinha achado ainda o meu agudo [risos]. (Jaqueline)

A presença da música junto aos familiares povoa as lembranças de Maria Helena (64 anos): “A minha mãe gostava de cantar. Meu irmão tocava pandeiro, mas cantar mesmo era minha mãe que cantava. Meu pai gostava muito de ouvir a gente cantar" (Maria Helena). Além de cantar, escutar música é uma prática musical bastante apreciada por ela, que tem em Alcione seu maior ídolo. Seu contato com a música se deu também através de um programa de rádio; ela recorda:

Desde quando eu era pequena que eu cantava. Cantei no Programa do Guri ${ }^{6}$, eu cantava com Elis Regina... participei lá por muito tempo. Não segui sempre porque minha mãe não deixava, dizia: "Onde se viu isso, ser cantora! Não vai ser essas coisas não”. Cantei muito tempo, eu fui rainha da primavera, fui rainha do carnaval e ai eu cantava nos salões, de 16 anos em diante eu já cantava nos salões, a voz ia lá longe, lá longe. Minha vida podia ter sido muito diferente se eu nunca tivesse parado de cantar. (Maria Helena)

Nessa direção, Tereza (67 anos), ao lembrar da sua juventude, revela que o rádio foi um canal de formação para ela: "A gente ligava o rádio e ia escutar

4 Tambor agudo de pequeno porte com duas peles vibrantes, comum em bandas e fanfarras.

5 Instrumento de percussão grave de forma cilíndrica, comumente usado em escolas de samba.

6 Programa radiofônico de auditório de Porto Alegre, entre os anos 1950 e 1966. Ficou conhecido por ter lançado nacionalmente Elis Regina. 
Vicente Celestino, Nelson Gonçalves. Era música como Lá vinha Mariana, A porteira velha, Menino da porteira, Alvarenga e Ranchinho [lembra cantando]. Depois vieram outras músicas bonitas, uma porção de gente nova, Cauby Peixoto [...]" (Tereza). De forma ainda similar, escutar música pela rádio era comum para Inocência (68 anos), que afirma que isso se tornou um hábito diário: "Se eu estou na cozinha sem música, até o serviço amarga. É bom começar o dia com o astral para cima e a música faz isso, bota a gente para cima" (Inocência).

Célia Outono (78 anos) também gosta de ouvir músicas no rádio e escutar CDs donde destaca os de Dorival Caymmi e Ary Barroso. É uma das poucas alunas na Escola que toca percussão - atabaque e pandeiro - na oficina de música (em geral são os estudantes homens que o fazem). Esse conhecimento adveio de experiências musicais oportunizadas pelo fato de ser mãe de santo no terreiro de umbanda em sua casa, embora como gosta de mencionar, também seja devota de Nossa Senhora das Graças.

De modo distinto das demais entrevistadas, o canto coral foi o espaço de formação musical de Iara (49 anos), que cantou no hospital onde trabalhava, e no qual pretende se reintegrar.

Como as demais práticas sociais, as práticas musicais são constituídas e compartilhadas através das relações pautadas por um determinado contexto sociocultural, donde no caso das mulheres em tela, a família e o rádio, apresentam-se como espaços importantes de formação musical quando crianças e jovens. Esses depoimentos mostram a música como um aspecto ativo da vida social dessas mulheres desde suas infâncias e juventudes, capaz de configurar situações sociais, conforme defende DeNora (2000), bem como espaços de aprendizagens.

\section{Práticas e aprendizagens musicais das mulheres na EJA}

Baseando-se nos relatos, pode-se afirmar que a música na Escola promove experiências que ultrapassam a dimensão do entretenimento, representando um espaço de formação. Várias mulheres, independentemente da idade, mostraram-se desejosas em aprofundar seus conhecimentos musicais e acreditavam ser esse o papel do ensino da música no CMET e não mero entretenimento - aspecto, aliás, colocado pela maioria dos demais participantes da pesquisa em tela. Algumas estudantes, como Ereni (65 anos), Jaqueline (32 anos), Maria Helena (64 anos) e Célia Primavera (30 anos) buscam se aprimorar como cantoras, outras querem aprender a tocar o violão, sendo este o caso de Iara (49 anos), Ereni (65 anos), e Jaqueline (32 anos) - esta inclusive deseja aprender a compor. Desse 
modo, a música na Escola tem levado a diversas aspirações. Enquanto Jaqueline mostra-se estimulada a formar sua própria banda, Célia Outono ( 78 anos), Célia Primavera (30 anos) e Ereni (65 anos) pretendem criar um trio vocal para cantar em barzinhos próximos a suas residências e/ou entre amigos(as) e familiares, e Iara (49 anos), deseja apropriar-se da grafia musical para desse modo cantar no coral da empresa em que trabalhava; e para ela a aula de música tem respondido a esse anseio.

Sobre a música em sala de aula e nas oficinas, as entrevistadas fazem diversas considerações, sobre os repertórios apreciados, o sentido que atribuem a essas atividades, incluindo as realizadas em público, entre outros aspectos. Célia Outono (78 anos) destaca o fato da oficina de música ser para ela um estímulo à superação da timidez, principalmente ao propiciar as apresentações: "Eu, que tinha vergonha, hoje já enfrento o público. Com as apresentações com o público, minha vergonha está saindo toda" (Célia Outono).

Iara (49 anos) comenta que há músicas que trabalham nas aulas que ela não escutaria em sua casa, mas que escuta na Escola "e até" gosta. Considera que "às vezes têm coisas que a gente não gosta, mas é porque a gente não entende. Quando tu passa a entender, tu passa a gostar. Tem muita coisa que eu não gostava que eu aprendi a gostar" (Iara, 49 anos). Entretanto, a aula adquire maior significado quando associada às suas preferências musicais (SOUZA, 2000), o que pode significar uma potencialidade de fortalecimento dos processos educacionais através da utilização da música, sendo vista, por exemplo, como uma expressão estético-artística a compor os elementos afetivos na aprendizagem e na recuperação de suas experiências e práticas sociais. Este foi o caso de Inocência (78 anos), que fala o quanto a música está presente em sua vida, inclusive como elemento que lhe transporta no tempo, revelando experiências e memórias musicais da sua infância e juventude. Isso se deu em parte pela inclusão, no repertório da aula, de músicas por ela conhecidas, como Barracão de Zinco (Luiz Antonio e Oldemar Magalhães). Música esta, que como conta, ela e os(as) colegas da sua faixa etária "já tinha muito ouvido falar". Ainda referindo-se a Barracão de Zinco, comenta: "para nós todos da minha idade, aquilo é um prato cheio. $O$ pessoal antigo cantava muito aquilo ali, então aquilo ali vai arrebentar [nas apresentações da Escola]" (Inocência). Trata-se de uma música que lhe remete a outros tempos. "Tempo de dançar de vestido comprido, saia engomada. Aqueles vestidos de chita, bailes nas colônias” (Inocência).

Ereni (65 anos) fala sobre o valor da sua experiência musical na Escola, como fator de desenvolvimento cognitivo e que fomenta a autonomia. Ela conta que surpreendeu a si mesma ao conseguir cantar para uma plateia: "Tenho muita coisa que aprender, mas eu nunca pensei que fosse abrir a boca em público para 
cantar, nem que fosse assim só para você eu já ia me sentir sem jeito, mas eu agora faço e gosto, gosto bastante [risos]" (Ereni).

Cabe ainda mencionar que as mulheres em sua grande maioria cantam e os homens tocam e cantam nas atividades musicais da Escola, ficando a execução instrumental delas restrita basicamente ao caxixi ${ }^{7}$ e às clavas ${ }^{8}$. Possivelmente esse comportamento está relacionado a experiências generificadas no âmbito da família, que restringiram possibilidades de interação dessas entrevistadas com a música. Como mencionado, por ser do sexo feminino, Diva (72 anos) não poderia participar como instrumentista na orquestra de baile do pai; Jaqueline (34 anos) e Maria Helena (64 anos) não puderam seguir cantando em espaços e tempos por elas desejados, entre outras situações de discriminação de gênero.

A música ao ser constituída por pessoas reflete valores culturais de indivíduos inscritos em uma determinada sociedade. Nesse sentido, Souza (2004) analisando as práticas musicais como fato social, chama a atenção para a interdependência da música com a dimensão sociocultural na qual ela é produzida. Como defende a autora, "esse entendimento mais ampliado sobre o significado social da música poderia ser útil para a compreensão das diferentes práticas musicais dos diversos grupos de estudantes na escola" (SOUZA, 2004, p. 8). $\mathrm{E}$ apoiada em Green, acrescenta que isso ajudaria inclusive a revelar "por que estudantes de diferentes grupos se envolvem em certas práticas, por que evitam outras e como respondem à música em sala de aula" (GREEN apud SOUZA, 2004, p. 8) - como é o caso das práticas musicais justo acima mencionadas pelas entrevistadas.

\section{Considerações finais}

Os depoimentos das mulheres entrevistadas mostram que o convívio escolar com colegas de diferentes gerações foi considerado como um aspecto positivo e de grande valor na escola pesquisada. A EJA foi considerada instigante justamente por ser um espaço de aprendizagem e compartilhamento entre estudantes de diferentes gerações, e por isso mesmo, promotor de apropriação e transmissão de saberes e experiências diversificadas. Entretanto, um questiona-

7 Pequeno chocalho em forma de campânula, feito de palha trançada.

8 Instrumento de percussão. Consiste de dois pequenos cilindros de madeira, percutidos um no outro. 
mento que emerge refere-se aos programas de formação inicial e continuada. Em que medida eles têm contemplado a dimensão intergeracional inerente à EJA?

No campo específico da arte, e mais especificamente da educação musical, tais programas parecem ser ignorados ou inexistentes, até o presente momento. Todavia, conforme os relatos sinalizam, a música se apresenta como uma prática social marcante nas experiências escolares das mulheres entrevistadas; inclusive várias delas mostram-se desejosas e conscientes de que a música no contexto da EJA possua uma função similar às outras áreas de conhecimento: promover aprendizagens (e não mero entretenimento). Relacionado a isso, suas falas revelam que a experiência educativo-musical na Escola tem lhes oportunizado superação da timidez, desenvolvimento cognitivo; elevação da autoestima; prazer; valorização pessoal social; compartilhamento estético; entre outras realizações.

\section{REFERÊNCIAS}

ARIÈS, P. História social da criança e da família. 2. ed. Trad.: Dora Flaksman. Rio de Janeiro: Guanabara, 1981.

BOURDIEU, P. A juventude é apenas uma palavra. In: BOURDIEU, P. Questões de sociologia. Trad.: Jeni Vaitsman. Rio de Janeiro: Marco Zero Limitada, 1983. p. 112-121.

BRANCO, V. A sala de aula na educação de jovens e adultos. Educar em Revista, Curitiba, n. 29. p. 157-170, jan./jun. 2007.

DEBERT, G. G. A reinvenção da velhice. São Paulo: EDUSP, 2004.

DENORA, T. Music in Everyday Life. Cambridge: Cambridge University Press, 2000.

FREITAS, M. F. Q. de. Educação de jovens e adultos, educação popular e processos de conscientização: intersecções na vida cotidiana. Educar em Revista, Curitiba, n. 29, p. 47-62, jan./jun. 2007.

HADDAD, S; PIERRO, M. C. Escolarização de jovens e adultos. Revista Brasileira de Educação, n. 14, p. 108-103, 2000.

LAFFIN, M. H. F. 2007. Reciprocidade e acolhimento na educação de jovens e adultos: ações intencionais na relação com o saber. Educar em Revista, Curitiba, n. 29, p. 100120, jan./jun. 2007.

LLORET, C. Las otras edades o las edades del outro. In: LARROSA, J.; PÉRES de LARA, N. (compilladores). Imágenes del otro. Barcelona: Virus Editorial, 1997. p. 11-20. 
MOLL, J. (Org.). Educação de Jovens e Adultos. Porto Alegre: Mediação, 2004.

MOTTA, F. M. Velha é a vovozinha: identidade feminina na velhice. Santa Cruz do Sul: EDUNISC, 1998.

OLIVEIRA, I. B. de. Reflexões acerca da organização curricular e das práticas pedagógicas na EJA. Educar em Revista, Curitiba, n. 29, p. 83-100, jan./jun. 2007.

OLIVEIRA, P. S. Vidas Compartilhadas: cultura e co-educação de gerações na vida cotidiana. São Paulo: HUCITEC; FAPESP, 1999.

PAIS, J. M. Culturas Juvenis. Lisboa: INCM, 1993.

RIBAS, M. G. C. Música na Educação de Jovens e Adultos: um estudo sobre práticas musicais entre gerações. Tese (Doutorado em Educação Musical) - Universidade Federal do Rio Grande do Sul, Porto Alegre, 2006.

SECRETARIA MUNICIPAL DE EDUCAÇÃO (SMED). Cadernos Pedagógicos $n^{\circ} 8$. Totalidades de conhecimento. Porto Alegre: SMED, 1997.

SMALL, C. Music, society, education: a radical examination of the prophetic function on music in Western, Eastern and African cultures with its impact on society and its use in education. 2. ed. Londres: John Calder, 1984.

SOARES, L.; VENÂNCIO, A. R. Tensões, contradições e avanços: a educação de jovens e adultos em uma escola municipal de Belo Horizonte. Educar em Revista, Curitiba, n. 29, p. 141-156, jan./jun. 2007.

SOUZA, J. F. (Org.). A Educação de Jovens e Adultos no Brasil e no mundo. Recife: NUPED/UFPE; Editora Bagaço, 2000.

SOUZA, J. Educação musical e práticas sociais. Revista da ABEM, v. 10, p. 7-11, 2004. (Org.). Música, cotidiano e educação. Porto Alegre: PPG Música/UFRGS, 2000.

VIANNA, H. Introdução. In: VIANNA, H. (Org.). Galeras Cariocas: territórios de conflitos e encontros culturais. 2. ed. Rio de Janeiro: Editora UFRJ, 2003. p. 7-16.

Texto recebido em 20 de maio de 2014.

Texto aprovado em $1^{\circ}$ de julho de 2014 . 